Sinergias educativas

ISSN: 2661-6661

compasacademico@icloud.com

Grupo Compás

Ecuador

\title{
Are english teachers really trained to deal with dyslexics?
}

Enri\#quez Lozano, Shirley Beatriz

Are english teachers really trained to deal with dyslexics?

Sinergias educativas, vol. 2, núm. 2, 2017

Grupo Compás, Ecuador

Disponible en: http://www.redalyc.org/articulo.oa?id=573561679004

Esta obra está bajo una Licencia Creative Commons Atribución-NoComercial-SinDerivar 4.0 Internacional. 


\title{
Are english teachers really trained to deal with dyslexics?
}

\author{
¿Los profesores de inglés están realmente capacitados para \\ tratar los disléxicos? \\ Shirley Beatriz Enríquez Lozano shirle.beatiz@hotmail.com \\ Profesora Unidad Educativa Nueva Semilla, Ecuador \\ (i) http://orcid.org/0000-0003-0263-37882
}

Sinergias educativas, vol. 2, núm. 2, 2017

Grupo Compás, Ecuador

Recepción: 15 Marzo 2017 Aprobación: 25 Noviembre 2017

Redalyc: http://www.redalyc.org/ articulo.oa?id $=573561679004$
Resumen: Objetivo: para garantizar un progreso académico sostenible en estudiantes disléxicos, este trabajo se basa en herramientas que ayudan a los profesores de inglés a manejar y evaluar los disléxicos adecuadamente. Método: La evaluación y el diagnóstico se realizaron a partir de la aplicación de protocolos cualitativos y cuantitativos del enfoque crítico, determinando, la adquisición del inglés como segundo idioma. Resultados: Después de la evaluación inicial, se hizo una propuesta como herramienta para los maestros que enseñan este segundo idioma. Un material importante proporcionado es una lista de estrategias y técnicas que permiten a los maestros guiarlos en el proceso de clase y evaluar a los estudiantes con esta dificultad de aprendizaje. Este recurso fue diseñado para ser aplicado en la evaluación diagnóstica, formativa y sumativa. Conclusión: es importante ofrecer a los disléxicos la oportunidad de ser enseñados y evaluados de acuerdo con sus propias habilidades. Los maestros también deben ser guiados para enfrentar este problema en el aula.

Palabras clave: Técnica, Disleccia, estrategias.

Abstract: Objective: In order to guarantee sustainable academic progress in dyslexic students, this work is based on tools that help English teachers manage and assess dyslexics properly. Method: The evaluation and the diagnosis were made from the application of qualitative and quantitative protocols of the critical approach, determining, the acquisition of English as a second language. Results: After the initial evaluation, a proposal was made as a tool for teachers teaching this second language. An important material provided is a list of strategies and techniques that allow teachers to guide them in the class process and evaluate students with this learning difficulty. This resource was designed to be applied in the Diagnostic, Formative, and Summative Assessment. Conclusion: It is important to offer dyslexics the opportunity to be taught and assessed according to their own abilities. Teachers also need to be guided to face this problem in the classroom.

Keywords: Dyslexia, Strategies, Techniques, Assessment, Skills.

\section{INTRODUCCIÓN}

Just a few years ago the term dyslexia had reference to psychologists. Nowadays, this term has been taken into the educative area due to the difficulties found by teachers when they face at least one case in their classroom ready enough to assess students with dyslexia. Consequently, this project will contribute to a group of colleagues who may have a handbook with different activities according to the level of dyslexia of each student. The beneficiaries of this project will be those students who may feel frustrated when developing a test that they cannot understand. 
The significance of this research is providing dyslexic students an opportunity to success in classes as well as in a test and giving teachers a tool to facilitate the normal development of children who have this kind of learning disability, so they can be incorporated in the medium or long term at the level they deserve without disadvantages.

As educators, we are motivated to focus our work in providing teachers the necessary tools to make dyslexic students engaged with English learning through appropriate learning techniques and assessments. Different teachers and educators have demonstrated that an increase of the use of appropriate strategies in a test will have better scores and therefore greater motivation in learning.

Within this frame of reference there are national and international authors who have done studies on the process of teaching and learning the English language in cases of students with dyslexia. Some of them refer to motivational strategies, others to evaluation.

But everyone has been interested in providing a tool to the teacher to include the dyslexic student in the didactic act. Serrano, in his doctoral thesis on the role played by phonology and spelling in the teaching and learning process of dyslexics, makes his contributions.

Serrano considers that children learn oral language because they are exposed in a natural way to the world around them and that written language deserves attention because it is a cultural process and demands grammatical structures. On the other hand, states that a dyslexic student learns best when his or her learning goes hand in hand with technology.

Both authors made important contributions, each in its own time. For in 2005 we still worked with emphasis on the concrete material in the classroom and the grammatical or orthographic rules that a student should know. While in 2014, the use of New Technologies in Communication and Information was booming and hence the use of this resource is necessary for the development of activities by a dyslexic student. Most importantly, the educator seeks alternative solutions to integrate dyslexic students into the regular classroom.

On the other hand, proposes in his thesis a teacher training in cognitive disabilities such as dyslexia and a guide to apply strategies for the acquisition of second languages. This author believes that a child who has not acquired a phonological awareness in their mother tongue will have difficulty interpreting a foreign phonological method in a foreign language.

However, Ecuador has given a look at the globalized world in the social, political, economic and educational. For this reason, there have been several studies conducted on the basis that English language learning reaches all students in a country. In addition, students with learning disabilities have the right to learn a second language within the context of their possibilities and with the support of educational professionals. In other words, as long as there is the motivation of both actors of the didactic act, it is possible to achieve a high degree of communication in English. 
In this regard, conducted a study with students up to six years of age at the Julio Verne Institute in Quito to develop an educational alternative for learning English in dyslexic students. His research was born from the problem that ignorance of the English language affects the performance of a child, but above all affects his emotional state until adulthood.

This work has been designed such that it has become a passage from the diagnosis of dyslexia, the learning areas affected, causes and types of dyslexia until its relationship to multiple intelligences. Furthermore, different teaching formats are provided to assess dyslexic students.

In other words, this research is a valuable resource to fulfill what the government demands about the special tests for students with special educational needs, in this case, dyslexia. That is why our project is divided into four sections, which are the introduction, the literature review, the research methodology and the final conclusions. The following section talks about the background of the problem and where it is located considering objectives, significance and scope of the study. The second section involves the conceptual information about our main concern which is dyslexia. The third section shows the statistics of our project and a brief explanation of what the results were. Finally, in the latter section, we provide our conclusions about the topic and the research instruments

\section{MATERIALES Y MÉTODOS}

Research Instruments In order to get the right information, an observation sheet, a survey, a general test, a pretest and posttest instruments were applied. The Observation Sheet determined the strategies and techniques used by the two teachers with dyslexic students. The Survey was applied to the sixty sixstudents in order to list the techniques used with them during the English classes. The General Test was given to the students in order to identify dyslexics. The Pretest with special techniques for

dyslexic students was given to realize how well they developed the evaluation. The Posttest was useful to determine that dyslexics can learn English.

\section{RESULTADOS}

The information obtained through the Tests, the Observation Sheet and the Inquiry was processed manually, applying double-entry tables and using the Descriptive Statistic. It was also shown in statistical graphics and percentage calculations. The observation sheet showed that teachers worked with the whole class in the same way, without making any kind of adaptation for dyslexics.

A general test was applied to the sixty- six students because the purpose was to identify the dyslexic students in each room. As soon as the results showed that any dyslexic could answer any question, part of our hypothesis was being proved. Finally, a pre-test was designed to be 
applied only to dyslexic students without any previous practice of special techniques. A post-test was also applied to the students as soon as they were trained in some techniques that covered the visual, acoustical, and spatial orientation areas.

Even though results from the pre-test were not totally successful, it is proved that scores were better than the ones gotten in the general test. It is also proved that results from the posttest were completely effective.

Tests for dyslexic students must take enough space in each exercise. It is necessary to guide the students in each single question development. In the case that their understanding was according to their learning style, it is important to read and gesture each instruction. As soon as the question is understood, they will be able to answer them with a high percentage of success.

Learning areas that can be affected in dyslexic students are reading and writing which are included in all the subjects; Math and time because dyslexics often get confused and write numbers backwards in operations; another matter is that they have difficulty telling the time but with the help of digital watches it is easier for them. Speech and Language, it is because a big number of dyslexic children were late talkers or had some sort of problems in their speech at first, but this was overcome through time. It is kind of hard for a dyslexic person to answer to a question or statement because it will take quite longer to process the information that has been said or asked. That is why a good way to help them is to reduce distractions and background noise to a minimal or even better try to eliminate them. This goes hand in hand to help these children with concentration which is another weak point for them. In some cases, speech therapy is required to improve this quickly.

Some orientations for English language teaching and learning in dyslexic students include Curricular Adaptations, which is the adjustment of one or more components of the general curriculum that the teacher of the subject makes to specify the proposed guidelines, keeping in mind the characteristics and needs of one or more students.

It is imperative that any dyslexic student receive a specific treatment, but it is crucial that their difficulty is addressed together in the classroom. School attendance should be primarily based on understanding the disorder, although avoidance of preservative measures should be avoided. It is necessary to make clear that the problem is biological and it is not a matter of being lazy or not having the desire to do what has to be done.

Besides, teaching materials are essential. English is communication and communication is technology, so audiovisual aids are mechanisms that attract the eyes and ears of students and the use of them has always been an integral part of education. These grants allow the English teacher to enrich and complement the curriculum, providing experiences as a basis for language development. In this way, learning English becomes easier. Although all the possible materials favor the learning of the students, it is important to give much value and use to the visual material.

In other words, visual aids are useful to maintain high the level of attention of the students; make students use language, especially in the 
beginning; encourage student participation; maintain and take care of the voice of the teacher; and help them save time in language teaching Because they can be used in all grades.

Creativity in a teacher when it comes to meaningful learning is important. This seems simple, but through the use of teaching materials you can reach the different learning styles of the students in the same classroom. In the case of dyslexic students, for example, there must be a series of materials that favor the surrounding learning environment.

In addition, for this group of students as well as for everyone in general, it will always be more dynamic and motivating to use the game, worksheets and concrete material, instead of just using the text, the marker and the board. It should be emphasized that all material to be used in the classroom should be in accordance with the activities to be developed. This congruence occurs when planning is done and the means of connection between the contents and the learning achievements to be achieved are sought.

\section{DISCUSIÓN}

Inclusive Education should be part of the existing teacher training curriculum. It means that schools should include in the teachers' profile the knowledge about laws that support this mandatory decision of the Ecuadorian government.

In order to facilitate the use of the agenda for dyslexic students, educational institutions should make them use different colors from line to line or colors according to the subject they teach. If a dyslexic student knew that red is for English, he would copy on the red line any simple instruction given by the teacher. This is really important because the school would be offering them the opportunity to be responsible with one of their duties which is listing homework in the agenda.

In addition, the school must establish a general rule that all students in the classroom share their phone numbers, so that any concerns or clarification in relation to the tasks can be explained with a partner by phone. The intention is not to make lower their effort level, but rather help the rest of the students promote their solidarity with children with special conditions.

The institution should be part of the law of inclusion through a pilot project on strategies used for students with dyslexia. It can be a host of parents of children with dyslexia or it can create an association of school families with dyslexic children in order to educate and train parents to help their children from home. It is necessary to emphasize that education is developed with the action of a triangle in which each side belongs to teachers, parents and students. Each actor is responsible of some actions, but if parents do not know how to help their children, teachers will progress slowly in their intentions to educate dyslexic students.

Parents and teachers should be assured that dyslexia is not a disease, but a condition a person is born with. It means that they should guarantee equal opportunities to learn English as a foreign language. There is a 
need to integrate confidence, accommodations, motivation, and suitable evaluation strategies.

Because dyslexia is not a term used exclusively for the psychological area, but also used in the educational field, it is a need to be trained on what to teach and how to assess dyslexic students. This training is the first step to face the management of teaching students with this condition in every single class.

Educators now have to continue adding information to this article in order to provide practical tools to make dyslexics learn English easily.

\section{Referencias}

Ashman, A. (2003). Supporting children with dyslexia. United Kingdom: The Question Publishing Company Ltd.

Bandura, A. (1990). Aprendizaje Social y desarrollo de la personalidad. Madrid: Alianza Editorial.

Blachman, B. (1997). Foundation Reading Acquisition and Dyslexia: Implications for early intervention. United Kingdom: British Library Cataloguing.

Finnochiaro, M. \& Bumfit, C. (1989). The Functional National Approach from Theory of Practice. Oxford: Oxford University Press.

Tomson, M. (2009). The Psychology of Dyslexia: A handbook for teachers. ESTADOS UNIDOS: Wiley-Blackwell

Turner, E. and Pughe, J. (2013). Dyslexia and English. London, UNITED KINGDOM: Fulton Publisher.

Bumfit, C. y Finocchiaro, M. (1983). The Functional National Approach, from theory to practice. New York: Oxford University Press.

Jime\#nez, N.P. Y Segovia, O.G. (2011). Diseño y aplicación de un manual para la prevención de la dislexia en las edades de 5 a 6 años en la escuela fiscal mixta club rotario de la ciudad de Latacunga en el periodo 2009-2010. Universidas Técnica de Cotopaxi, Ecuador

C.H.Patterson. (1982). Bases para una teorit\#a de la ensen\#anza y psicologi\#a de la educacio\#n. New York, Estados Unidos: El manual moderno.

Caiza, L. (6 de 2012). INFLUENCIA DE LA DISLEXIA EN EL PROCESO DE LA LECTO- ESCRITURA EN LOS NIÑOS DELTERCER AÑODE EDUCACIÓN BÁSICA DE LA ESCUELA FISCAL MIXTA PABLO NERUDA DURANTE EL AÑO LECTIVO 2010-2011. Universidad Central del Ecuador, Ecuador.

Center, D. R. (2013). Easy Reaing Card. USA: Dyslexia Research Center. Recuperado de http://www.easy-reading- card.com/.

Kurnoff, S. (2000). The human Side of Dyslexia. USA: London Universal. 